\title{
思いやり尺度の作成と妥当性の検討'
}

\author{
京都大学 内田由紀子 ${ }^{2} \cdot$ 北山忍
}

\section{Development and validation of a sympathy scale}

Yukiko Uchida and Shinobu Kitayama (Graduate School of Human and Environmental Studies, Kyoto University, Yoshida-nihonmatsucho, Sakyo-ku, Kyoto 606-8501)

The authors developed a 22-item scale of interpersonal sympathy that is informed by relevant practices and meanings of contemporary Japanese cultural context. In three independent samples the scale was shown to be reasonably reliable $(\alpha>80)$. Furthermore, the scale had a systematic relationship with related variables, hence exhibiting satisfactory construct validity. Specifically, sympathy was positively correlated with both a reported frequency of prosocial behaviors (Study 1) and emotional empathy (Study 2). Moreover, sympathy formed a higher-order factor with interdependent construal of self, which was orthogonal to another higher-order factor comprised of independent construal of self and self-esteem (Study 3). Finally, some directions for future research are discussed.

Key words: sympathy, Japanese culture, interdependence.

心理学における近年の比較文化研究では, 相互協調 性（Markus \& Kitayama, 1991)，集団主義（Triandis， 1995), あるいは社会中心性 (Shweder \& Bourne, 1984）などが東洋の諸文化の特徵としてあげられてい る.これらの理論的立場はいずれも東洋の文化が他者 志向的であるという点に打いて一致している。しか し, 他者志向性の具体的形態は個々の文化や文化内の サブグループによって異なっている可能性がある。特 に日本文化に抢いては，他者志向性はしばしば“思い やり”という概念によって成り立っていることが指摘 されている（レビューは Kitayama \& Markus (1999) 参照)。たとえば日本における対人関係では, 契約的 な取り決めによる“互酬性”よりも情による結びつき や思いやりが重んじられる（浜口，1988）。また，他 者の立場に立って自分に言及する語用法（母親が子ど もに向かって自分のことを“お母さん”と呼ぶなど） が定着しているが(鈴木，1973），これは思いやりに 基づいた行動傾向が高度に慣習化した例である。同様 の現象は他者知覚においてもみられる。日本人は当人

1 本研究は, 内田が北山の指導のもと, 京都大学教育学部に 提出した卒業論文に基づいている. 本研究は文部省科学研究費 による補助（基盤研究 B：“日本的自己の諸相：矛盾と統合の夕” イナミックス”，代表者：北山忍）を受けた。

2 日本学術振興会特別研究員.
の立場をとり，その “気持ち”に注目することが多い ため,たとえ相手が道徳的に問題のある行為をしたと しても寛容な判断をしがちである（東，1994）。さら に，土居（1980）は“甘え”を日本文化に扔ける中心 的感情であると論じたが，甘えとは，他者からの思い やりの（いささか過度な）期待であると解釈しうる (山口，1998)。

これらの知見から，日本に抢ける自己や関係性の性 質を理解する際, 思いやりの文化慣習とそれに連動し た心理傾向を系統的に探索する必要があると考えられ る. その第一歩として, 思いやり傾向の個人差を測定 する尺度を開発することの意義は高い，従来，思いや りや共感性についてはいくつかの尺度が用いられてき ているが，後述のように，それらがどの程度日本にお ける思いやりという心理傾向を包括的に測定している かについては多少の疑問が残る。そこで本研究では, この点に留意して新たな尺度の開発を目指した。

従来の思いやりの概念についての研究を概観してみ ると，思いやりに含まれる心理傾向には大別して三つ のものがあることがうかがわれる、第一は，向社会的 行動への動機づけである. 実際, 共感性や思いやり研 究の多くは向社会的, 愛他的行動との関連で数多くな されてきている（レビューは杉森（1996）を参照；原 田・狩野，1980；伊東，1996；菊池，1988，1998；鈴 木, 1992；高木, 1998). 
思いやりに含まれる第二の要素として，菊池をはじ めとする多くの研究者は, 相手の感情状態を的確に判 断し，相手と同じ感情を感じるという“共感能力”を 挙げている（Eisenberg \& Mussen, 1989 菊池・二宮 訳，1991；菊池，1988，1998)。この点は第一の点と 密接に関連している。それというのも相手に共感すれ ば，特に相手がなんらかの手助けを必要としているよ うな場合には，向社会的な行動の頻度が高まると予測 されるからである。

第三に，相手の気持ちの直感的理解（察し）を挙げ ることができる。この場合，相手と同じ感情状態を経 験する必要はない。むしろ重要なのは，相手からいわ れるまでもなくその人物の気持ちをわからうとする傾 向とその能力である. 向社会的動機づけと共感性の二 つの要素は，洋の東西を問わず思いやりを定義する際 に広範に用いられているが，“察し”は特に日本文化 に扔いて重要視される点であると考えられる。実際 Travis（1998）は，日本文化に打ける思いやりの重要 性を指摘したうえで，それを相手の気持ちの直感的理 解（察し）とそれに基づく行動であると定義してい る。Travisは，“察し”の概念は特に日本語の“思い やり”に含まれる概念であり，英語の“sympathy” や“empathy”にはこれが含まれていないことを指摘 している.

これらの知見を総合して，本研究では思いやりには “他者の気持ちを察し，その人の立場に立つて考える こと”，そのうえで “その気持ちや状態に共感もしく は同情する”こと，そして“向社会的行動の動機づけ となる”という三つの側面があると仮定する.

既存の尺度においては，これら三つの側面が同時に は考慮されていない，たとえば，加藤・高木（1980）

は，情動的共感性尺度を作成したが，これはもつぱら 相手と同じ感情を経験するという意味での共感 (empathy) に注目している。桜井（1988）によって 日本語訳されたDavis（1983）による多次元共感測定 尺度も同様に共感㲹着目したものである。また，対人 的価值尺度（ゴードン・菊池，1981）の下位尺度の一 つに“他の人のためになることをする気持ちを大切に 思うかどうか”という，思いやりの気持ちを扱った “博愛的価值” の尺度があるが，これは博愛主義とい う価值観を支持するかどうかについての認知的判断を 扱ったものであり，思いやり的な心理・行動傾向の測 定をめざしたものではない。また菊池（1988，1998） は，日本に扔ける思いやり行動を，(1)結果として相 手のためになり，(2)ある種のコストを含むが，(3)返 報や扔礼を目的に行われるものではなく，(4)自発的 になされる，という四つの事項で定義し，これに対応 した思いやり行動の頻度を測定する尺度（向社会的行 動尺度）を作成した（菊池，1988）。しかし，この尺 度が报う思いやり行動は，そのような行動の準備状態
としての思いやり的心理状態とは理論的に区別される べきであろう。そこで本研究では，上記の三つの意味 の要素を包括的に含む思いやり尺度の開発をめざし た。

\section{研究 1 思いやり尺度の作成}

\section{方 法}

被験者と手続き 大学生 12 名に, “思いやりのある 人（ない人）はどういう人だと思いますか”という質 問に自由記述での回答を求めたところ，(1)困ってい る人の心情を察すること, (2) その人の立場に立って, 共感し，暖かい気持ちを向けること，(3)その人に愛 他的にふるま扔うとすること，という先述の理論的定 義に合致しているものが多くみられた，そこでこれら の記述を参考にして思いやりを測定すると考えられる 55 項目を用意した (うち 16 項目が逆転項目)。これ らを質問紙にランダムに並べ，大学生男女 127 名（男 性 97 名, 女性 30 名，年齢 18-25才）に示し，それ ぞれが自分にあてはまる程度を 5 件法で回答させた (1＝全くあてはまらない，5＝非常によくあてはま る).

さらに尺度の妥当性についての手がかりを得るため に，人に対する喛かい行動三つ(“人からもらい泣き をしたことがある”“映画やテレビを見て涙がでたこ とがある”“困っている人をかわいそうに思って助け たことがある”）と，冷淡な行動二つ(“困っている人 を無視したことがある”“何かで失敗した人を責めた ことがある”) のそれぞれを行ったことがあるかどう かを回答させた。

\section{結 果}

逆転項目のスコアを 6 から引き，これらの項目の総 和得点が高いほど思いやり傾向が強いようにしたうえ で，主因子法による因子分析を行い固有值を検討した ところ，第 4 因子までは固有值が減り続けるが第 5 因 子以降の減少はほとんどみられなかった 因子解が妥当であると判断した。 バリマックス回転後 の因子構造を検討したところ，第 1 因子には弱い者へ の親切心, 第 2 因子には涙も万さ,さらに第 3 因子に は他者に対する厳しさ (逆転項目), そして第 4 因子 には苦労や不幸への共感にかかわる項目がそれぞれ高 い負荷をもつていた。これらは先の定義に合致する結 果である。そこでそれぞれの因子内から，(1)意味や 状況がなるべく多様になり，(2)全体として逆転項目 が潘平数になり，(3)因子への因子負荷量がなるべ く高いもの 22 項目（うち逆転項目 10 項目）を選び,

3 固有值は第 1 因子から順に，7.82，2.81，2.64，1.94，1.52, 1.36, 1.31，1.07，0.97，0.78であった。 
思いやり尺度とした（Table 1)。

これら 22 項目を対象に因子分析したところ, 固有 値は第 1 因子解が 4.34, 第 2 因子解が 1.52 , 第 3 因子 解が 0.70 であった。ここから 1 因子解か 2 因子解の いずれかが妥当であると判断できる。そこで，これら 二つの解の関係を吟味したところ，2因子解は 1 因子 解に含まれる涙もろさに関する4 項目 (“自分は涙も ろいほうだとは思わない”，“もらい泣きしやすいほう だ”, “いわゆる“扔涙項戴もの”の映画は好きではな い”，“映画やテレビドラマを見てよく泣く”）が分離 して成立していることがわかった。これらの 4 項目は 1 因子解を採用した場合には，第 1 因子に含まれてい た. 2 因子解において第 1 因子を構成する項目の平均 值と第 2 因子を構成する項目の平均值は, 正方向で相 関していた $(r=.37, p<.001)$ ，そこでわれわれの当 初の目的が “思いやり”という感情状態の包括的尺度 の作成であることを勘案し, 本尺度に㧈いては 1 因子
解を採用することにした。当初の 4 因子解がこの分析 で 1 因子解となった理由については, 各項目には項目 間の共通性とそれ以外の意味があったためと考えると わかりやすい. 多数の項目を用いて因子分析する場合 には，全項目には共通しない意味が四つの因子という かたちで浮かび上がったのに対し，項目数を減ずると 相対的に共通性の比重が増し, その結果因子の数が減 ったと考えられる。第 1 因子の説明率は全分散の 19.8 \%で必ずしも高くはなかったが，これは内容を多岐に わたらせた結果であると考元られる。実際，思いやり 尺度の信頼性は十分に高いものであった $(\alpha=.84)$.

尺度の平均值をみたところ，22 項目の尺度の全体 では 3.23 であった。過去の知見（菊池，1988）と一 致して, 平均值は女性のほうが男性よりも有意に高か った $(M=3.42$ vs. $3.15, t(125)=2.28, p<.03)$.

加えて, 思いやり傾向と援助行動との関連について も検討した。それぞれの行動指標で，暖かい行動を

Table 1

思いやり尺度

\begin{tabular}{|c|c|c|c|}
\hline & 項 目 & 因子負荷量 & 項目-全体得点相関 \\
\hline \# 1 & 自分は涙もろいほうだとは思わない & .35 & $.40^{* * *}$ \\
\hline$\# 2$ & 一生懸命やっても失敗すれば意味はないと思う & .21 & $.32 * *$ \\
\hline 3 & つらい思いをしている人のために祈るような気持ちになることがある & .46 & $.45^{* * *}$ \\
\hline$\# 4$ & 試合で自分が勝つためならば相手が怪我をしていても容赦しない & .39 & $.47^{* * *}$ \\
\hline 5 & 頑張っている人を見ると応援したくなるほうだ & .54 & $.49^{* * *}$ \\
\hline \# 6 & 情にほだされたくない & .56 & $.62^{* * *}$ \\
\hline 7 & もらい泣きしやすいほうだ & .44 & $.52 * * *$ \\
\hline \#8 & 人が失敗した場合その人に責任があるので同情の必要はない & .33 & $.39^{* * *}$ \\
\hline 9 & $\begin{array}{l}\text { バスや電車で抢年寄りや障害のある方が立っていたら席を譲ってあげないと } \\
\text { 可哀想だと感じる }\end{array}$ & .40 & $.46^{* * *}$ \\
\hline \# 10 & 人のつらい話を聞いても心からは同情できない & .36 & $.42 * *$ \\
\hline$\# 11$ & 仲間に入れない人がいてもそれはその人の責任だと思う & .33 & $.34^{* * *}$ \\
\hline 12 & 泣いている子供を見たらついやさしく声をかけたくなる & .52 & $.56^{* * *}$ \\
\hline \#13 & いわゆる“扔涙頂戴もの”の映画は好きではない & .52 & $.57^{* * *}$ \\
\hline 14 & 人を思いやることが何よりも大切だと思う & .41 & $.46^{* * *}$ \\
\hline 15 & 自分が物事が順調な場合，そうでない友人のことを思うと申し訳なく感じる & .39 & $.45^{* * *}$ \\
\hline 16 & 人に対しては常に親切でいようと思う & .51 & $.54^{* * *}$ \\
\hline 17 & 自転車が将棋倒しになっているのを見たら，起こしてあげたいなと思う & .54 & $.57^{* * *}$ \\
\hline 18 & ニュースで事故などの報道に接すると心が痛んでしまう & .43 & $.45^{* * *}$ \\
\hline$\# 19$ & 一人一人の主張がぶつかることによって傷つく人がいても仕方がないと思う & .37 & $.41^{* * *}$ \\
\hline$\# 20$ & 弱い立場にある人も自分で何とかするべきだ & .39 & $.46^{* * *}$ \\
\hline 21 & 苦労話を聞くと心を打たれる & .61 & $.59 * * *$ \\
\hline \multirow[t]{2}{*}{22} & 映画やテレビドラマをみてよく泣く & .49 & $.55^{* * *}$ \\
\hline & 説明率 $(\%)$ & 19.8 & \\
\hline
\end{tabular}


“行ったことがある”場合と冷淡な行動を“行ったこ とがない”場合を 1 点, その逆を 0 点として, 行動指 標 5 項目の得点総和を求め, 援助行動得点とした（得 点範囲：0-5).この点数と思いやり尺度の間には有 意な正の相関がみられた $(r=.35, p<.001)$ 。また, これらの相関が思いやり尺度のなかに含まれる “涙も ろさ”に関する 4 項目との重複によるものであるかど うかを検討するため, 涙もろさに関する 4 項目以外の 18 項目の平均值との相関係数を算出したところ, 相 関は多少弱くはなったものの, 依然として正の方向で 有意であった $(r=.25, p<.01)$.この結果は, 思いや り的心理傾向は援助行動を促進するというこれまでの 知見を追認するものであり, 尺度の妥当性を示してい る.

\section{研究 2 思いやりと情動的共感性}

思いやり尺度の概念的妥当性は, 思いやり傾向と理 論的に関連した心理傾向との相関をみることにより確 認できる。この目的のために, 研究 2 では情動的共感 性を取り上げた。情動的共感性とは，他人が情動状態 を経験していると理解した結果，観察者に生じた情動 状態のことである（Stotland，1969）。先に述べたよう に, 他者への共感は思いやりの構成要素の一つである と考えられる。この点は共感と思いやりの発達につい ての論考とも一致する．たとえば，Hoffman (1975) は, 共感 (empathy) という原初的感情傾向が自他表 象という高次の認知機能と統合されて, 思いやり (sympathy) 傾向が生まれてくると主張した。する と, 各人の思いやり傾向は情動的共感性と強く相関す るであろう。

\section{方 法}

被験者と手続き Mehrabian \& Epstein (1972) が 作成した尺度に基づいて作成された情動的共感性尺度 （加藤・高木，1980）と研究 1 で作成した思いやり尺 度との相関を検討した。大学生男女 90 名（男性 48 名, 女性 42 名, 年齢 18-22才）にこれら二つの尺度
項目をランダムに混ぜて示し，5件法で回答させた (1＝全くあてはまらない，5＝非常によくあてはま る).

\section{結 果}

情動的共感性尺度は “感情的暖かさ” “感情的冷淡 さ”“感情的被影響性”の三つの下位尺度からなる。 共感性が高いほど感情的に暖かく, 冷淡ではなく, 被 影響性は高いと考えられる。“感情的冷淡さ”の䐜目 を逆転項目として分析を行ったところ，Table 2 にま とめたように, これら三つの下位尺度の信頼性はいず れも高かった $(\alpha$ 欄). 思いやり尺度の信頼性係数も 研究 1 同様十分に高かった。加藤・高木による先行研 究（1980）に一致して, 各尺度の平均得点は, 女性の ほうが男性より高かった。次いで情動的共感性と思い やり傾向との相関をみたところ, 思いやりと感情的暖 かさ, 感情的冷淡さの間には非常に強い相関がみられ た $(r=.72, p<.001, r=.70, p<.001)$. また, 感情的 暖かさと冷淡さの相関も高かった $(r=.55, p<$ .001)。これに対して感情的被影響性は, これら 3 変 数と正の方向で相関していたが, その数值は相対的に 弱かった。思いやりは，相手の立場に立ってその人の ためになるように考えることであり，単に相手と同じ ような感情を自動的に感じるという以上のものを含む と考えられる (Eisenberg \& Mussen, 1989 菊池・二 宮訳，1991). 感情的被影響性が思いやり傾向とは比 較的相関が低いという結果は，このような分析に適合 している。

思いやり尺度と情動的共感性尺度の相関は, 思いや り尺度に情動的共感性尺度に含まれる項目（涙もろさ に関する項目）があるためである可能性がある。そこ で，思いやり尺度 22 項目から涙もろさに関する 4 項 目を取り除いた值とも同様の相関がみられるかどうか を検討したところ, 感情的暖かさとは $r=.72(p<$ $.001)$, 感情的冷淡さとは $r=.69(p<.001)$, 感情的 被影響性とは $r=.32(p<.01)$ というょうに，いずれ に扔いても涙もろさに関する項目を含んだ場合と同程

Table 2

思いやり尺度と情動的共感性尺度

\begin{tabular}{|c|c|c|c|c|c|c|}
\hline & \multirow{2}{*}{$\alpha$} & \multicolumn{2}{|c|}{ 平均 $(S D)$} & \multicolumn{3}{|c|}{ 相関 } \\
\hline & & 男 $(N=48)$ & 女 $(N=42)$ & 2 & 3 & 4 \\
\hline 1. 思いやり尺度 & .85 & $3.15(.61)$ & $3.58(.42) * * *$ & $.72 * * *$ & $.70^{* * *}$ & $.35^{* *}$ \\
\hline \multicolumn{7}{|l|}{ 情動的共感性尺度 } \\
\hline 2. 感情的暖かさ & .69 & $3.43(.66)$ & $3.90(.32)^{* * *}$ & & $.55^{* * *}$ & $.33 * *$ \\
\hline 3. 感情的冷淡さ & .66 & $3.31(.59)$ & $3.66(.48)^{* *}$ & & & $.32 * *$ \\
\hline 4. 感情的被影響性 & .62 & $3.19(.68)$ & $3.61(.63) * *$ & & & \\
\hline
\end{tabular}


度の相関が得られた。

これらの結果は，思いやり傾向には相手に対して共 感し，暖かい感情を向けることが含まれるとする我々 の分析に一致する。さらに今回の結果は, 菊池 （1988）の報告した向社会的行動尺度と情動的共感性 尺度との相関とほほ同様の傾向のものであった（菊 池, 1988，1998).

\section{研究 3 思いやりと相互独立性, 相互協調性}

思いやり尺度の概念的妥当性をさらに検討するため に，研究 3 では自己認識にかかわる変数を取り上げ た。近年の文化心理学の理論的分析によると，欧米の 社会に存在する日常的習慣や社会制度，さらにはさま ざまな常識的理解の枠組みには，(1)人とは周りから 切り離され独立し，(2) 意見・態度・能力・動機・性 格特性などといった永続性や一貫性をもった内的な属 性によって定義づけられた存在であり，(3)その行動 はこのような内的属性にしたがって，周囲に影響を与 える手段である，というモデル（相互独立的自己観） に基づいて成り立っているものが多いとされる。これ に対して，東洋の社会に存在する文化の諸要素には， (1)人とは周囲と密接に結びつき，(2)そのような結び つきを通じて生まれる社会的関係性のなかで定義づけ られた存在であり，(3) その行動は社会的関係性に自 らを調整していくものであるというモデル（相互協調 的自己観）に基づいて成り立つているものが多いとさ れる（Markus \& Kitayama，1991）。そして特に日本文 化に扔いて思いやりに基づいた文化慣習が多くみられ るというこれまでの知見から考察すると，相互協調的 自己観は“思いやり”という形態をとって日本社会の なかに歴史を通じて根付いてきたと考えられる。これ ら文化レベルの慣習に反映された自己観は，個人レべ ルの行動傾向にも反映されているであろう。なぜな ら，行動傾向や性格特性などにみられる個人差は，当 該の文化慣習や常識を受け入れ，それにそって行動し たり，あるいはそれらを拒絶し，それと反するように 行動したりする程度の個体間の分散のことであると考 えられるからである。

思いやりとは相互協調性の一側面であるとすると, 各人の思いやり的心理傾向と相互協調性の間には強い つながりがあると予測できる。さらに，相互協調性と 独立性とは一般に独立の次元であることから，思いや りは相互独立性とは結びついていないことが予測され る。これらの予測を検証するために研究 3 では, 研究 1で開発した思いやり尺度と Singelis（1994）による 相互独立性 (independence), 相互協調性 (interdependence）尺度との間の相関を検討した。加えて，これ らの心理傾向と各人の自尊心の程度との関連も検討し た。思いやりが相互協調性の現れの一つの形態である ように, 自尊感情は相互独立性の現れの一つであると
したら（Kwan, Bond, \& Singelis, 1997)，自尊傾向は 相互独立性とは正の相関をもつが，相互協調性や思い やり傾向とは独立であろうと予測される。

\section{方 法}

被験者と手続き大学生男女 125 名（男性 81 名, 女性 44 名，年齢 $18-23$ 才）に，思いやり尺度， Rosenberg(1965) の自尊心尺度（山本・松井・山成 訳，1982; Heine, 1996) ${ }^{4}$, Singelis (1994) による相 互独立・相互協調性尺度の邦訳版 (Heine, 1996) ${ }^{5}$ に 5 件法（1＝全くあてはまらない，5二非常によくあては まる）で回答させた。

\section{結 果}

用いた 4 尺度の信頼性は, Table 3 の $\alpha$ 欄に示した ようにお抢むね高いものであった，特に思いやり尺度 は, 研究 1 や 2 同様, 十分な信頼性を有していた。 各尺度の平均值を男女別に分析したところ（Table 3 参照), 思いやり尺度の得点は女性のほうが高かった が，自尊心，相互独立性，協調性に関しては男女差は みられなかった。次いでこれら 4 変数の相関をみたと ころ, 予測どおり思いやりは相互協調性と $(r=.55$, $p<.001)$, 自尊心は相互独立性と $(r=.30, p<.001)$ それぞれ正の相関を示した.さらに，思いやりは自尊 心や相互独立性とは相関をもたず $(r=.02, n s, r=$ $.06, n s)$, 自尊心は相互協調性とは相関をもたなかっ た $(r=-.04, n s)$. 最後に相互独立性と協調性の間 には弱い負の相関がみられた $(r=-.19, p<.05)$.こ れらの結果から，思いやりは相互協調性と，また自尊 心は相互独立性と結びつき，ほぼ独立の因子を構成し ているさまがうかがわれる。この点を確認するため に, 思いやり, 相互協調性, 自尊心, 相互独立性の 4 変数を対象に主因子法による因子分析を行いバリマッ クス解を求めたところ, Table 4 にまとめたように, 前者二つは第 1 因子に, 後者二つは第 2 因子に高い負 荷をもった。この結果は，思いやりが相互協調性の下 位概念を構成し, 自尊心が相互独立性の下位概念を構 成するという可能性と適合する。

4 山本他の訳（1982）をもとに，Heine（1996）が訳出したも のを用いた。“全体的に私は自分自身に満足している”“私はも っと自尊心がもてればいいのになと思う”（逆転項目）など 10 項目.

5 相互独立性尺度は“自立できることは私にとってとても重 要なことである”“いろいろな面で他の人とは違うユニークな自 分が好きである”，など 14 項目．相互協調性尺度は “自分の所 属するグループの中で調和を保つことは私にとって大切である” “私注しばしば自分の業績よりも他人とのつきあいのほうが大切 だと感じる”, など 15 項目。 
Table 3

思いやり，自尊心，相互独立・協調尺度の信頼性，平均値と相関

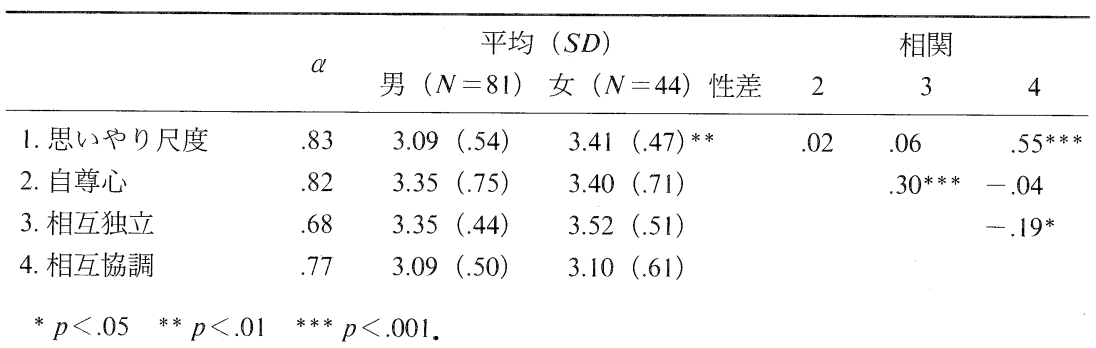

Table 4

思いやり尺度，自尊心尺度， 相互独立・協調尺度 の因子分析

\begin{tabular}{lcc}
\hline & 第 1 因子 & 第 2 因子 \\
\hline 思いやり & .73 & .11 \\
相互協調 & .79 & -.17 \\
自尊心 & .01 & .36 \\
相互独立 & -.05 & .80 \\
説明率 $(\%)$ & 28.9 & 20.4
\end{tabular}

\section{考 察}

本研究では, 日本文化に抢ける思いやりの概念の重 要性を指摘したうえで，思いやり傾向の個人差を測定 する尺度を開発した。 三つの独立のサンプルを対象に した調査からこの尺度は十分な信頼性をもつことが示 された。次いで，尺度の妥当性を検討するために他の 関連指標との相関をみたところ，思いやり傾向ととも に向社会的行動傾向は増加し (研究 1), またそれは 情動的共感性と高い正の相関を示した（研究 2).さ らに，思いやりは相互協調性と正方向で相関するが, 相互独立性や自尊心とはほほ独立であること，そして 後者二つは正方向で相関するため，思いやりと相互協 調性, 自尊心と相互独立性のそれぞれは高次の直交因 子を構成することを示した（研究 3 ). 今後この尺度 を用いて，“相互思いやり的”と仮定さ机る日本にお ける人間関係の深層をより綿密に検討することが可能 になるであろう。実際我々は，思いやり傾向ととも に，向社会的行動傾向や他者加の援助傾向の主観的 頻度が増加するという結果を得ている（北山・内田， 1998)。この事実は，日本においては思いやり傾向は 援助行動を動機づけるばかりでなく, 他者からの援助 を誘発するため互恵関係の予測因ともなっていること を示している.

従来の比較文化的アプローチのなかでは, 相互協調 性という高次の概念に注目した尺度（たとえば，伊 藤，1993；木内，1995； Singelis，1994; 高田，1995）
が用いられてきた。これに対して我々は高次の概念で ある相互協調に含まれる要素の一つである“思いや り”に注目して尺度作成を行った。相互協調のなかに は, 伝統・規律・役割・協力などのさまざまな下位概 念が含まれているが，このなかでも思いやりは社会関 係への情緒的関与の指標であると考光られる。今後は 相互協調などの高次の概念に注目した尺度と同時に， 思いやりなどの特定の側面に注目した尺度を併用する ことにより，より理論的な分析が可能になると考えら れる。

最後に, 思いやりなどの他者との情緒的関与は, 人 類に比較的共通にみられる特性であるとされている。 たとえばSmith（1976）は “sympathy”を仲間意識 (fellow feeling) と名付け, 集団の凝集性の基盤であ るとした。今回我々は特に日本の文化慣習を勘案して 思いやり尺度を作成したが，この尺度が日本以外の文 化における社会関係への情緒的関与の程度の測定に際 しどの程度の妥当性をもつかは, 今後の研究により明 らかにしていく必要がある。そのような試みを通じ て, 社会関係への情緒的関与が個及の文化により多様 な形式で育まれているさまが明らかになることであろ う.

\section{引用文献}

東 洋 1994 日本人のしつけと教育 東京大学出版 会

(Azuma, H. 1994 Japanese discipline and education. Tokyo: Tokyo University Press.)

Davis, M. H. 1983 Measuring individual differences in empathy: Evidences for a multidimensional approach. Journal of Personality and Social Psychology, 44, 113-126.

土居健郎 1980 甘元の構造 弘文堂

(Doi, T.)

アイゼンバーグ N.・マッセン P. H. 菊池章夫・二宮 克美（訳） 1991 思いやり行動の発達心理 金子 書房

(Eisenberg, N., \& Mussen, P. H. 1989 The roots of prosocial behavior in children. Cambridge and New York: Cambridge University Press.) 
ゴードン L.V.・菊池章夫 1981 価值の比較社会心 理学—理論と測定法—増補版川島書店

(Gordon, L. V., \& Kikuchi, A. 1981 Social psychology of values. Tokyo: Kawashima Shoten.)

浜口恵俊 1988 “日本らしさ”の再発見 講談社 (Hamaguchi, E.)

原田純治・狩野素朗 1980 援助行動に及ぼすパーソ ナリティ要因の効果 九州大学教育学部紀要（教育 心理学部門), 25, 83-88.

(Harada, J., \& Kano, S. 1980 The effects of personality factor on helping behavior. Research Bulletin of the Faculty of Education (Educational Psychology Section), Kyushu University, 25, 83-88.)

Heine, S. J. 1996 Culture and the need for positive self-regard: The Japanese case. Unpublished doctoral dissertation, University of British Columbia.

Hoffman, M. L. 1975 Altruistic behavior and the parent-child relationship. Journal of Personality and Social Psychology, 31, 937-943.

伊東秀章 1996 援助行動の質——援助の質の高さと 関連する性格特性とジェンダー——実験社会心理 学研究, 36, 261-272.

(Ito, H. 1996 The quality of helping behavior. Japanese Journal of Experimental Social Psychology, 36, 261-272.)

伊藤美奈子 1993 個人志向性・社会志向性尺度の作 成及び信頼性・妥当性の検討 心理学研究, 64, 115122.

(Ito, M. 1993 Construction of an individual and social orientedness scale and its reliability and validity. Japanese Journal of Psychology, 64, 115-122.)

加藤隆勝 - 高木秀明 1980 青年期における情動的共 感性の特質 筑波大学心理学研究, 2, 33-42.

(Kato, T., \& Takagi, H. 1980 Characteristics of the emotional empathy in adolescence. Tsukuba Psychological Research, 2, 33-42.)

菊池章夫 1988 思いやりを科学する一一向社会的行 動の心理とスキル——川島書店

(Kikuchi, A.)

菊池章夫 1998 また/思いやりを科学する 川島書 店

(Kikuchi, A.)

Kitayama, S., \& Markus, H. R. 1999 Yin and yang of the Japanese self: The cultural psychology of personality coherence. In D. Cervone \& Y. Shoda (Eds.), The coherence of personality: Social cognitive bases of personality consistency, variability, and organization. New York: Guilford. Pp. 242302.

北山 忍 - 内田由紀子 1998 日本的自己と相互思い やり的人間関係—尺度作成と仮説の検証一百 日 本グループ・ダイナミックス学会第 46 回大会発表 論文集, 270-271.

(Kitayama, S., \& Uchida, Y. 1998 The Japanese selves and mutually sympathetic relationship: Development and validation of a scale. The 46th Annual
Meeting of the Japanese Group Dynamics Association, 270-271.)

木内亜紀 1995 独立 - 相互依存的自己理解尺度の作 成及び信頼性・妥当性の検討 心理学研究, 66, 100106.

(Kiuchi, A. 1995 Construction of a scale for independent and interdependent construal of the self and its reliability and validity. Japanese Journal of Psychology, 66, 100-106.)

Kwan, V. S. Y., Bond, M. H., \& Singelis, T. M. 1997 Pancultural explanations for life satisfaction: Adding relationship harmony to self-esteem. Journal of Personality and Social Psychology, 73, 1038-1051.

Markus, H. R., \& Kitayama, S. 1991 Culture and the self: Implications for cognition, emotion, and motivation. Psychological Review, 98, 224-253.

Mehrabian, A., \& Epstein, N. 1972 A measure of emotional empathy. Journal of Personality, 40 523543.

Rosenberg, M. 1965 Society and the adolescent self-image. Princeton: Princeton University Press.

桜井茂男 1988 大学生における共感と援助行動の関 係 奈良教育大学紀要, 37, 1 (人文・社会) , 149-153. (Sakurai, S. 1988 The relationship between empathy and helping behavior in college students. Bulletin of Nara University of Education, 37, 1 (Cultural and Social Science), 149-153.

Shweder, R. A., \& Bourne, E. J. 1984 Does the concept of the person vary cross-culturally? In R. A. Shweder \& R. A. LeVine (Eds.), Culture theory: Essays on mind, self, and emotion. Cambridge, England: Cambridge University Press. Pp. 158-199.

Singelis, T. M. 1994 The measurement of independent and interdependent self-construals. Personality and Social Psychology Bulletin, 20, 580-591.

Smith, A. 1976 The theory of moral sentiments. In D. D. Raphael and A. L. Macfie (Eds.). New York: Oxford University Press.

Stotland, E. 1969 Exploratory investigations of empathy. In L. Berkowitz (Ed.), Advances in experimental social psychology. Vol. 4. New York: Academic Press. Pp. 271-314.

杉森伸吉 1996 共感性と向社会的行動 览童心理学 の進歩, 35, 158-192.

(Sugimori, S.)

鈴木隆子 1992 向社会的行動に影響する諸要因一 共感性・社会的スキル・外向性——実験社会心理 学研究, 32, 71-84.

(Suzuki, T. 1992 Some factors influencing prosocial behavior: Empathy, social skill and extraversion. Japanese Journal of Experimental Social Psychology, 32, 71-84.)

鈴木孝夫 1973 ことばと文化 岩波書店

(Suzuki, T.)

高木 修 1998 人を助ける心一援助行動の社会心 理学——サエンス社 
(Takagi, O.)

高田利武 1995 日本的自己の構造一一下位様態と世 代差一 心理学研究, 66, 3, 213-218.

(Takata, T. 1995 The structure of self in Japanese culture: Aspects and age differences. Japanese Journal of Psychology, 66, 3, 213-218.)

Travis, C. 1998 Omoiyari as a core Japanese value: Japanese-style empathy? In A. Angeliki \& T. Elzbieta (Eds.), Speaking of emotions: Conceptualization and expression. Berlin: Mouton de Gruyter. Pp. 55-81.

Triandis, H. C. 1995 Individualism and collectivism.
Boulder, CO: Westview Press.

山口 勧(編著) 1998 社会心理学——アジ的視点 から—— 三訂版 放送大学教育振興会

(Yamaguchi, S.)

山本真理子・松井 豊・山成由紀子 1982 認知され た自己の諸側面の構造 教育心理学研究, 30, 64-68. (Yamamoto, M., Matsui, Y., \& Yamanari, Y. 1982 The structure of perceived aspects of self. Japanese Journal of Educational Psychology, 30, 64-68.)

- 1999.1.21 受稿, 2001.1.13 受理- 